\title{
Triple Bottom Line Reporting: An Assessment of Sustainability in Banking Industry in Nigeria
}

\author{
Oluwagbuyi Olusola Luke \\ Department of Accountancy, School of Business Studies \\ The Federal Polytechnic, Ado-Ekiti, Ekiti State, Nigeria \\ Adaramola Anthony Olugbenga (Corresponding author) \\ Department of Banking and Finance, Faculty of Management Sciences \\ Ekiti State University, Ado-Ekiti, Ekiti State, Nigeria \\ E-mail: gbengaadaramolaunad@yahoo.com
}

Received: May 14, 2013 Accepted: September 27, 2013 Published: December 1, 2013

doi:10.5296/ajfa.v5i2.4121 URL: http://dx.doi.org/10.5296/ajfa.v5i2.4121

\begin{abstract}
Triple bottom-line reporting is an emerging issue in accounting profession in Nigeria that aims at assessing and enhancing corporate performance with regards to sustainability. It widens the scope of traditional reporting which emphasises financial profitability. It considers the contributions of a corporate organisation towards the environmental and social sustainability thereby giving more attention to stake holders than shareholders. The primary objective of this study is to investigate whether triple bottom line reporting contributes significantly to sustainability of banking firms in Nigeria. In our analysis of data, the descriptive statistical analysis was used to evaluate the study. 400 questionnaires were administered on the senior and management members of staff in the 22 banks in Nigeria after re-consolidation. The data were analysed using chi-square statistical techniques. Also, annual reports of the 22 banks spanning from 2009-2011 were examined. The findings show that emphasis is still on financial profitability of the banking industry in Nigeria. The study hereby recommends that for sustainability to be enhanced in banking industry in Nigeria, adequate attention should be given to the environmental and social sustainability to complement financial profitability.
\end{abstract}

Keywords: Triple Bottom Line Reporting, Sustainability, Environment and Social Value, Dimensional Measurement Reporting 


\section{Introduction}

Group 100 (2003) submitted that the trend towards greater transparency and accountability in public reporting and communication is reflected in an organisation's effort towards more comprehensive disclosure of corporate performance to include the environmental, social and economic dimensions of an entity's activities. This trend is a shift from the traditional objective of maximisation of the wealth of the shareholders to ensuring that stakeholders are adequately cared for in the scheme of corporate planning, execution and appraisal.

The traditional goal of a business centres on economic performance. However with the current global trend of social sustainability, the senior management must endorse and be committed to environmental and social obligations; even though these may have major resources implications to corporate goals and results. Triple bottom line reporting is hinged on improved relationship among stakeholders; especially employees, customers and investors. It is believed that the adoption of triple bottom line reporting in banking firms in Nigeria will lead to the enhancement of their reputations and brands. Among other things, it will also guarantee an adequate social responsibility, improved access to investors, reduction in risk profile, identification of cost savings potential, increased scope of innovation, identification of stakeholders' needs with management focus and creation of an opportunity for stakeholders' dialogue.

The aggregation of the afore mentioned variables has been widely believed will engender a robust banking operation in an economy. It is against this backdrop that this paper seeks to assess the sustainability of banking industry in Nigeria if the triple bottom line standard is adopted.

\section{Literature Review}

Tilt (2007) posited that sustainability accounting (also known as social accounting, social and environmental accounting, corporate social reporting, corporate social responsibility reporting or non-financial reporting) was originated about 20 years ago and is considered a sub category of financial accounting that focuses on the disclosure of non-financial information about a firm's performance to external parties such as capital holders, creditors and other stakeholders. This is the report of activities of a firm that have direct impact not only on the economic performance, but also on the business environment and the society at large.

Sustainability accounting in contrast with financial accounting is used for internal decision making and the creation of new policies that have effect on the organisations performance of economical, ecological and social (known as the triple bottom line or triple - P's, people, planet, profit) level.

Global reporting initiative was established with the goal to provide guidelines to organisations' reporting on sustainability. It states that 'reporting on economic, environmental and social performance by all organisations should be seen as a routine and be made comparable to financial reporting' (http://www.globalreporting.org). 
El Kington (1988) opined that the triple line reporting focuses corporations not just on the economic value they add, but also on the environmental and social value, frame work for measuring and reporting corporate performance against economic, social and environmental parameters.

Tavis (2004) submitted that sustainability is driven by the desire to improve an organisation's measure of progress across an integrated social, environmental and economic platform. He stated further that sustainability has emerged as a guiding principle and value-laden construct that integrates issues of the environment with issues of development and society, while the concept has become a "principle" bench mark, its application has promoted wide debate and often confusion. It is often interpreted in sectoral (development, agriculture, fisheries, industry etc.) and dimensional (environment, social, economic) contexts at varying scales (local, national and international). This led to the conclusion of Meadows (1989) that the consequence of this is that sustainability can mean different things to different players but that the highest level of management should be guided by a common set of principles and objectives.

Tavis (2004) also submitted that inherent in sustainability is the assumption that development must meet the ongoing needs of current and future generations, including the inequalities in the distribution of goods and services. This requires societal orientation, resources conservation, development with ecological limits, environmental protection and restoration. It also requires good governance, transparency, democracy and participation. Decision making must take an integrated approach that includes social, economic and environmental issues with reference to its basis as a social construct that applies to human society and culture. Tavis therefore concluded by saying that ultimately sustainability is about doing things better and improving our environment, our society and economies.

Suggett and Goodsir (2000) identified several generic characteristics of Triple bottom line initiative to include accountability, transparency, integrated planning and management commitment to stakeholders' engagement and multi dimensional measurement reporting.

Fred (2006) claimed that triple bottom line theory claims to be a reporting mechanism is designed to encourage businesses to give closer attention to the whole impact of their commercial activities rather than just their financial performance. It is probably the best known among non-financial reporting formats to have been given serious attention over recent years. It is defined by the Mc-Grand Hill book publishing organisation as "a calculation of corporate, economic, environmental and social performance” Elkington (1977) opined that the triple bottom line reporting implies that businesses should give parity of treatment to these three dimensions of business impact without giving unique weight to their financial result. It focuses on non-financial reporting rather than just the economic value of business activities. Brundland (1987) defined sustainability as "development which meets the needs of the present without compromising the ability of future generations to meet their own needs.

In its 2002 reporting guidelines, the Global Reporting Initiative (GRI) emphasized the need to develop techniques that enhance the ability of business to report more consistently and more 
comprehensively on the economic, environmental and social dimensions of their activities, products and services. The GRI's objective is to enhance the quality of sustainability reporting. Today, the triple bottom line reporting is the format most commonly chosen by businesses for the purpose of reporting. The speed at which triple bottom line reporting has been adopted by the business community is quite remarkable. Its geographical spread is equally impressive. Business support, however does rest on at least one de factor proviso. That is triple bottom line reporting should not be interpreted to mean that companies are not expected to maximise returns across the three dimensions of performance but rather that financial performance is recognised as the primary consideration in assessing business success (Group 100, 2003)

According to Price Waterhouse Coopers (PWC) "Management Barometer” survey of 14 different advanced economies, 68\% of large corporations in western Europe and $41 \%$ in the United States were reporting on the triple line in the second quarter of 2002 (PWC, 2002)

Price Waterhouse Cooper commented: 'with the current breakdown of confidence in financial reporting, large companies are facing increasing demands and expectations from stakeholders, and corporate organisations are being held more accountable for their performance and actions'.

The triple bottom line reporting approach is a proactive step in providing shareholders with increased transparency and broader framework for decision making. It is a great way for companies to disclose meaningfully their non-financial results.

KPMG conducted an international survey of what they call "corporate sustainability reporting” every three years. Although sustainability reporting is not quite the same as triple bottom line reporting, reports of most firms always include an environmental component, which is one of the features of triple bottom lines. For KPMG survey of 2002, the most recent available, we learn that environmental, social or sustainability report from 2000 companies were assessed; these included the top half of the fortune 500 group and the top 100 companies in 19 countries. According to KPMG, the result of the survey demonstrates that this kind of reporting is becoming mainstream business and no longer restricted to sectors with high environmental impact in western countries but also in non-industrial sectors and other region (KPMG, 2002). The report documented a $29 \%$ increase in the number of companies from the fortune 500 sample publishing report in 2002, compared with 1999. It goes to state that the survey of top companies across 19 countries showed that Japanese companies reported most (72\%) followed by the UK (49\%) and that within the United States and Western Europe as a whole 30-40 percent of companies report. These companies represent a huge corporate commitment to triple bottom line reporting.

In addition, there is no doubt that the spate of corporate scandal experienced around the world has raised interest in triple bottom line reporting especially in the United States and Europe. Triple bottom line reporting is also gaining popularity in Africa. This is obvious in South Africa, where the second report on governance standards by King (2002) gave a direct boost to triple bottom line reporting. The King report explicitly stated that corporate citizenship was becoming an established fact in business life and that there was a need for companies to 
report on their continuing sustainability in terms of environmental responsibilities, including their interpretation of, and response to social responsibility. Fred (2006) however concluded that triple bottom line reporting places more responsibilities towards the stakeholders rather than shareholders. Conceptually, it brings to an end the myopic view of shareholders as the driver of business policy. Instead triple bottom line reporting integrates stakeholders' interests into business policy and the interests which each organization must strive to meet.

Buffin (2004) said: 'There is no question that our society has become less paternalistic and more individualistic. Individual good seems to be taking precedence over the common good. There's more change and uncertainty. Jobs are for now, not for life. And in the suburbs and the regions, too many people are feeling excluded. With this sense of powerlessness, frustration is growing and what's more, people are making their feelings known. They are saying to companies; look at it through our eyes; add empathy to your corporate strategies. To those of us in leadership roles they are saying - we expect more'. Scheiwiller (2005) opined that few can disagree with the first part of this statement. However, there are evidences in support of the latter part of the statement. For example, he asserted that a group of Europe's investors controlling US $\$ 900$ billion in assets have written to 20 of the world's top pharmaceutical companies outlining the steps they believe the firms could take reduce the risks to the industry's reputation from crisis.

It is in view of the needed support from our multinational companies that this paper examines the concept of triple bottom line reporting as a reliable compliment to the concept of sustainability in banking industry in Nigeria. It critically assesses the approach of banking industry in Nigeria towards triple bottom line reporting.

\section{Method and Materials}

Both primary and secondary methods of data collections were adopted. For the primary data collection: The research designed used for the study was descriptive research of the survey type. The population comprised of the members of staff of the 20 banks in Nigeria after re-consolidation namely: Access bank, Guarantee Trust Bank, Wema Bank, Mainstreet bank, First Bank, Union Bank, United Bank of Africa, Skye Bank, Eco Bank, Enterprise Bank, Diamond Bank, Keystone Bank, Zenith Bank, Unity Bank, Sterling Bank, IBTC Bank, FCMB Bank, Fidelity Bank, Standard Chartered Bank and Citi Bank.

In the course of the study, average of twenty (20) questionnaires were distributed in each of the banks to the top ranking officers, not less than senior managers. The total was four hundred (400) to all twenty banks with the help of research assistants. 400 were returned by the respondents. Secondary data were also collected through the collection of annual report of these banks from 2009-2011. These enabled us to access the corporate obligation to triple bottom line reporting standard.

\subsection{Research Questions}

i. Do adequate water ways and erosion control have any significant relationship with the sustainability of banking industry? 


\section{Macrothink}

Asian Journal of Finance \& Accounting

ISSN 1946-052X

2013, Vol. 5, No. 2

ii. Can ensuring of weed control and contribution to access road have any relationship with sustainability of banking industry?

iii. Can solid waste control and management have any significant relationship with environment in which a bank operates?

iv. Does pollution as a result of emission from generators and other electronic machines have any significant relationship with the sustainability of the banking industry?

v. Does contribution towards adequate security of the community in which a bank operates have any relationship with its sustainability?

vi. Can employee and their family welfare significantly affect the productivity and overall result of the banking industry?

vii. Does work force stability have any significant relationship with the result of the operations within the banking industry?

viii. Does provision of facilities such as employment of disabled and the less privileged who are qualified have any significant relationship with corporate sustainability?

ix. Do provision of scholarship awards in the community, donations to community, sponsorship of talents in games and sports have any significant relationship with the goodwill of the banking industry?

\subsection{Research Hypotheses}

i. Adequate waste water ways and erosion control have no significant relationship with the sustainability of banking industry.

ii. Ensuring weeds control and contribution to access road have no significant relationship with sustainability of banking industry.

iii. Solid waste control and management have no significant relationship with environment in which a bank operates.

iv. Pollution as a result of emission from generators and other electronic machines has no significant relationship with the sustainability of the banking industry.

v. Contribution towards adequate security of the community in which a bank operates has no significant relationship with its sustainability.

vi. Employees and their family welfare do not significantly affect the productivity and overall result of the industry.

vii. Stability in the workers' turnover has no significant relationship with the result of the operation in the banking industry.

viii. Employment of disables and less privileged who are qualified has no significant relationship with corporate sustainability of the banking industry. 
ix. Scholarship award in the community, donations to community, sponsorship of talents in games and sports have no significant relationship with the goodwill of the banking industry.

\section{Results and Discussion}

Research Hypothesis 1: Adequate wastage ways and erosion controls have no significant effect on the sustainability of banking industry.

Chi- square $\left(\mathrm{x}^{2}\right)$ result

\begin{tabular}{|l|l|l|l|}
\hline Diff & $x^{2}$ calculated & $x^{2}$ table value & Level of significance \\
\hline 4 & 8.18 & 7.18 & $5 \%$ \\
\hline
\end{tabular}

Source: Authors' computation

$\mathrm{X}^{2}$ calculated value 8.18 while $\mathrm{x}^{2}$ critical value is 7.81 . Our analysis fails to accept the null hypothesis. Therefore, the research hypothesis stating that adequate waste ways and erosion control have significant effect on sustainability of banking industry is accepted

Research Hypothesis 2: Weeds control and participation in access road construction have no effect on the sustainability of banking industry.

Chi square $\left(\mathrm{x}^{2}\right)$ result

\begin{tabular}{|l|l|l|l|}
\hline Diff & $x^{2}$ calculated & $x$ table value & Level of significance \\
\hline 4 & 14.2 & 7.81 & 0.05 \\
\hline
\end{tabular}

Source: Authors' computation

$\mathrm{X}^{2}$ calculated value is 14.2 while $\mathrm{X}^{2}$ critical value is 7.81 . This confirms that the alternative hypothesis is accepted indicating that needs control and participating in access road construction have significant effect on the sustainability of baking industry in Nigeria.

Research Hypothesis 3: Solid waste management and control has no significant relationship with the environment in which banks operate.

Chi - square $\mathrm{x}^{2}$ result

\begin{tabular}{|l|l|l|l|}
\hline Diff & $x^{2}$ calculated & $x^{2}$ table value & Level of significance \\
\hline 4 & 58.16 & 7.81 & 0.05 \\
\hline
\end{tabular}

Source: Authors’ computation

The alternative hypothesis stating that solid waste management and control has significant effect on the environment in which banks operate is accepted since $x^{2}$ calculated value of 58.16 is greater than $\mathrm{x}^{2}$ table value of 7.81 .

Research Hypothesis 4: Pollution as a result of emission from power generators and other electronic machines has no relationship with the sustainability of the banking industry 


\section{Al Macrothink}

Chi-square $\mathrm{x}^{2}$ result

\begin{tabular}{|l|l|l|l|}
\hline Diff & $\mathrm{x}^{2}$ calculated & $\mathrm{x}^{2}$ table value & Level of significance \\
\hline 4 & 4.14 & 7.81 & 0.05 \\
\hline
\end{tabular}

Source: Authors’ computation

The $\mathrm{x}^{2}$ calculated it 4.14 while $\mathrm{x}^{2}$ critical value is 7.81 . Our analysis here fails to reject the null hypothesis. This implies that pollution as a result of emission from power generators and electronic machines has no significant effect on sustainability of the banking industry in Nigeria.

Research Hypothesis 5: Adequate security of the community in which a bank operates has no relationship with its sustainability.

Chi-square $\mathrm{x}^{2}$ result

\begin{tabular}{|l|l|l|l|}
\hline Diff & $\mathrm{x}^{2}$ calculated & $\mathrm{x}^{2}$ table value & Level of significance \\
\hline 4 & 155.9 & 7.81 & 0.05 \\
\hline
\end{tabular}

Source: Authors' Computation

Since $\mathrm{x}^{2}$ calculated value as 155.9 which is greater than $\mathrm{x}^{2}$ table value which is 7.81 , therefore the alternative hypothesis indicating that adequate security of the community in which a bank operates has a significant effect on its sustainability is accepted.

Research Hypothesis 6: Health care for employees and their families has no significant effect on effectiveness, efficiency and overall result of the banks.

Chi-square $\mathrm{x}^{2}$ result

\begin{tabular}{|l|l|l|l|}
\hline Diff & $\mathrm{x}^{2}$ calculated & $\mathrm{x}^{2}$ table value & Level of significance \\
\hline 4 & 49.22 & 7.81 & 0.05 \\
\hline
\end{tabular}

Source: Authors' computation

Since $\mathrm{x}^{2}$ calculated value as 49.22 and $\mathrm{x}^{2}$ table value as 7.81 , the alternative hypothesis stating that health care for employees and their families has a significant effect on effectiveness, efficiency and overall result of the banks is accepted.

Research Hypothesis 7: Work force stability has no significant effect on the result of operations in the banking industry.

Chi-square $\mathrm{x}^{2}$ result

\begin{tabular}{|l|l|l|l|}
\hline Diff & $x^{2}$ calculated value & $x^{2}$ table value & Level of significance \\
\hline 4 & 97.46 & 7.81 & 0.05 \\
\hline
\end{tabular}

Source: Authors' computations 
The alternative hypothesis stating that work force stability has a significant effect on the result of operations in the banking industry is accepted since $x^{2}$ calculated value is greater than $\mathrm{x}^{2}$ critical value.

Research Hypothesis 8: Banks’ social responsibility such as scholarship awards to students in the communities, donations to communities and sponsorship of talents in games and sports has no significant effect on the goodwill of the industry.

Chi-square $\mathrm{x}^{2}$ result

\begin{tabular}{|l|l|l|l|}
\hline Diff & $x^{2}$ calculated value & $x^{2}$ table value & Level of significance \\
\hline 4 & 25.26 & 7.81 & 0.05 \\
\hline
\end{tabular}

Source: Authors' computation

$\mathrm{x}^{2}$ calculated value is 25.26 while, $\mathrm{x}^{2}$ table value is 7.81 . Therefore, the research hypothesis stating that banks' social responsibility such as scholarship awards to students in the communities, donations to communities and sponsorship of talents in games and sports has no significant effect on the goodwill of the industry is accepted.

Research Hypothesis 9: Employment of physically challenged persons and the less privileged who are qualified has no significant effect on corporate sustainability of the industry.

Chi-square $\mathrm{x}^{2}$ result

\begin{tabular}{|l|l|l|l|}
\hline Diff & $x^{2}$ calculated value & $x^{2}$ table value & Level of significance \\
\hline 4 & 13.52 & 7.81 & 0.05 \\
\hline
\end{tabular}

Source: Authors’ computation

Since $\mathrm{x}^{2}$ calculated value is 13.52 which is greater than $\mathrm{x}^{2}$ critical value of 7.81 . Therefore, the alternative hypothesis stating that employment of physically challenged persons and the less privileged who are qualified has a significant effect on corporate sustainability of the banking industry is accepted.

\subsection{Discussion of Findings}

A critical analysis of the study Triple bottom line Reporting: an assessment of sustainability in banking industry in Nigeria revealed the following facts: Adequate participation in the management of wastage ways and erosion control can have positive impact on the sustainability of baking industry in Nigeria.

Furthermore, the study discovered that environmental need control and construction of access road as a social responsibility is positively significant to the sustainability of banking industry in Nigeria.

Also, it is explicitly revealed that effective participation in the security of the community in which a bank operates can positively enhance the sustainability of the banking industry in Nigeria. 
Equally, the study all allows us to discover that adequate and sufficient health care for the employees and their family members can engender effectiveness, efficiency and sustainability of the banking sector.

Findings also revealed that work force stability is an indispensable strategy for sustainability of banking industry in Nigeria.

Finally, the study revealed that discharging corporate social responsibility such as scholarship awards for the children of high intelligent quotient, talented children in games and spirits, employment of physically challenged and less privileged persons who are qualified can have positive result in sustainability of the banking industry in Nigeria.

\section{Summary, Conclusion and Recommendations}

\subsection{Summary of Findings}

Evaluation of triple bottom time reporting in relation to the sustainability in banking industry in Nigeria shows that if Nigeria banking sector can adopt the triple bottom line reporting. It will enhance the sustainability of the industry since it will affect all the stakeholders positively rather than the current traditional reporting which hinged more on financial reporting alone. Triple bottom line reporting takes into consideration the concept of fairness and objectivity. It embraces the factors that can affect environment, employees and finance.

This hybrid approach to reporting enables corporate organizations to be conscious of their social, financial and environmental responsibilities. Corporate organizations as entities cannot live in isolation. They have to be fully aware that they affect their environment in a way. Triple bottom line reporting allows the corporate organizations to understand that as a subset of the large organizations, they must be ready to contribute to the wellbeing of the society. Elkington (1988) opined that the triple bottom line reporting focuses corporations not just on the economic value they add, but also on the environment and social values they add or destroy. At its narrowest, the term triple bottom line reporting is used as a frame work for measuring and reporting corporate performance against economic, social and environmental parameters. It also enhances transparency.

\subsection{Conclusion}

Considering all the discoveries in this study, we can assert the fact that Triple bottom line reporting will show three balance sheets which will show the statement of affairs in relation to economic activities of the reported organizations. Also it will qualitatively analyze how organizational activities affect the environment in which the an organization operates possibly in terms of infrastructure, provision of good health facilities, involvement in funding of the educational sector. This is in line with the comments of Price Waterhouse Cooper (2002) as a result of the current breakdown of confidence in financial reporting. Large companies are facing increasing demands and expectation from stakeholders and corporate organization are being more held accountable for their performance and actions.

Also the stability of the work force and welfare has to be clearly reported. The development programmes that enhance the quality of the workers force. The care for the family of the 
employees and all the on-the-job and retirement facilities including the turnover of the work force has to be reported.

Finally, we conclude that adoption of triple bottom will facilitate sense of belonging to all stakeholders which will enhance sustainability to the banking industry in Nigeria.

\subsection{Recommendations}

a) Since triple bottom line is a trend towards transparency and accountability, the Central Bank of Nigeria should include it in its policy and make it compulsory for all banks.

b) The Central Bank of Nigeria should mandate all the banks to itemize and analyze their financial reports to reflect how the stakeholders are affected by the activities of the year.

c) The Central Bank of Nigeria should make a policy that include non-share holders in the annual general meetings and allow to participate in the issues that affect their environment.

d) Triple bottom line reporting should be included in the curriculum of relevant courses and professional bodies

e) Finally the generic characteristics of triple bottom line initiative should include integrated planning and management commitment to stakeholders engagement and mull dimensional measurement reporting.

\section{References}

Brundland, G. (1987). Our common future: The world commission on Environmental and Development. Oxford University Press U.K

Buffin, F. (2004). Business takes on a social role Sydney: the Australian financial Review Nov 19. P.10, Australia.

El Kington, J. (1988). Cannibals with Forks; the sustainability ability and Social Science, round table proceedings, Capstone publishing U.K

El Kington J. (1977). Cannibals with Forks; the Triple bottom line of $21^{\text {st }}$ century Business Oxford capstone publishing U.K

Fred, R (2006). The challenge of TBL; A responsibility of whom? Business and society review 11:1, 1-14 Blackwell publishing, 350 Main street, Maiden MA 02148 U.S.A and 9600 Carsington Road Oxford OX42DQ U.K.

Global Reporting Initiative. (2002). Sustainability Reporting Guidelines http://www.globalreporting.org. Accessed Jan 18, 2005

Group 100, (2003). An association of Australian senior fiancé executives from national business enterprise; sustainability guide to triple bottom line reporting Sydney; group of 100 incorporated Australia. H.//www.globalreporting.org 


\section{Macrothink}

Asian Journal of Finance \& Accounting

ISSN 1946-052X 2013, Vol. 5, No. 2

KPMG (2002). KPMG international survey of corporate sustainability reporting 2002. KPMG Global sustainability service June 24 De Meern Nether lands.

Meadows D. (1989). indicators and information sustainable development sustainable institute V.T.U.S.A

Mervyn King. (2002). Second Report on Governance Standards in South Africa, retrieved from: www.ecgi.org/codes/documents/executive_summary.pdf on August 8,

Price Waterhouse Coopers. (2002). “management barometer” price waterhouse coopers BSI Global research, September 26 http://www.barometersurveys.com /production /bar survensfl, accessed January 25, 2005.

Scheiwiller T. (2005). Corporate responsibility in pharmaceutical industry. Price water house coopers news letter http://www.pwc.com/Extweb/pwc publications nsf accessed January 25, 2005.

Suggett D., \& Goodsir B. (2000). Triple Bottom Line Measurement and Reporting in Australia, Allen consulting group, Canberra.

Tavis, P. (2004). Triple bottom line reporting, a tool for measuring, communicating and facilitating change in local government a paper for the effective sustainability education conference 2004. Sinth Sydney city Council Australia

Tilt C.A. (2007). Corporate Responsibility Accounting and Accountants. Idowu Samuel O, Leafilho water (EDS). Perspective of corporate social responsibility D0110.10071/978-3-6x2-02630-02, Springer Verlag Berlin Heidelberg 2009. 